\title{
Wstrzymanie wykonania zastępczej kary pozbawienia wolności w trybie art. 65a k.k.w.
}

\author{
Kamila MrozeK \\ Zakład Prawa Karnego Wykonawczego \\ Wydział Prawa, Administracji i Ekonomii Uniwersytetu Wrocławskiego
}

Ustawa z dnia 6 czerwca 1997 r. Kodeks karny wykonawczy w pierwotnym brzmieniu przewidywała dwie formy zastępczego wykonania kary ograniczenia wolności. Jeżeli skazany uchylał się od odbywania kary ograniczenia wolności, sąd zamieniał ją na zastępczą karę grzywny, przyjmując jeden dzień kary ograniczenia wolności za równoważny jednej stawce dziennej (art. $65 \S 1$ k.k.w.). Jeżeli natomiast skazany, mimo możliwości wykonania zastępczej kary grzywny, nie uiścił jej w terminie, a zostało stwierdzone, że nie można jej ściągnąć w drodze egzekucji, sąd zarządzał wykonanie zastępczej kary pozbawienia wolności (art. $65 \S 3$ k.k.w.). Co ciekawe, już wyżej powołana ustawa przewidywała możliwość wstrzymania wykonania zastępczej kary pozbawienia wolności. Jeżeli skazany wyrażał gotowość natychmiastowego podjęcia pracy związanej z wymierzoną mu karą ograniczenia wolności, sąd mógł wstrzymać wykonanie kary zastępczej do czasu odbycia kary ograniczenia wolności ${ }^{1}$. Podstawą wstrzymania wykonania zastępczej kary pozbawienia wolności było zatem podjęcie przez skazanego nakazanej mu pracy i poddanie się

${ }^{1}$ S. Pawela, Kodeks karny wykonawczy. Praktyczny komentarz z indeksem rzeczowym, Warszawa 1999, s. 205.

Nowa Kodyfikacja Prawa Karnego 46, 2017

(C) for this edition by CNS 
rygorom z nią związanym. Zapis ten budził jednak w doktrynie poważne wątpliwości. Po pierwsze wyjaśnienia wymagało pojęcie ,podjęcia nakazanej pracy”, po drugie zaś określenie ,poddania się rygorom z nią związanym". Wskazywano, iż mimo braku ustawowego doprecyzowania pierwszego z problemów pod pojęciem pracy należało rozumieć nie tylko obowiązek wykonywania nieodpłatnej kontrolowanej pracy na cele społeczne, ale również potrącenie $\mathrm{z}$ wynagrodzenia za pracę na podstawie art. $35 \S 2$ k.k., na co zwracał uwagę R. Giętkowski². Rygory związane $z$ pracą to nie tylko obowiązek sumiennej pracy oraz przestrzegania ustalonych w miejscu pracy porządku i dyscypliny, ale ogół obowiązków spoczywających na konkretnym skazanym na karę ograniczenia wolności, z wyjątkiem jego podstawowego obowiązku, jakim jest obowiązek wykonywania nakazanej mu pracy ${ }^{3}$.

Ustawą z dnia 16 września 2011 r. o zmianie ustawy — Kodeks karny wykonawczy oraz niektórych innych ustaw ${ }^{4}$ wprowadzono istotne zmiany w obrębie wykonywania kary ograniczenia wolności. Zrezygnowano bowiem z majątkowej formy zastępczego jej wykonania oraz możliwości wstrzymania wykonania zastępczej kary pozbawienia wolności w trybie art. $65 \S 5$ k.k.w. W uzasadnieniu do rządowego projektu wyżej powołanej ustawy podkreślano, iż ,kara łagodniejsza rodzajowo (a taką jest grzywna) nie powinna być karą zastępczą orzekaną za uchylanie się od wykonania kary rodzajowo surowszej. W przypadku zatem uchylania się skazanego od odbywania kary ograniczenia wolności, sąd zarządzał będzie wykonanie zastępczej kary pozbawienia wolności"5. Wskazywano, iż przyczyną rezygnacji z rozwiązania przyjętego w art. $65 \S 5$ k.k.w. jest dążenie do szybkości, efektywności i sprawności postępowania karnowykonawczego ${ }^{6}$.

2 Por. R. Giętkowski, Skutki uchylania się od odbywania kary ograniczenia wolności, „Państwo i Prawo” 2006, nr 7, s. 90-91.

3 Ibidem.

4 Ustawa z dnia 16 września 2011 r. o zmianie ustawy - Kodeks karny wykonawczy oraz niektórych innych ustaw, Dz.U. 2011, Nr 240, poz. 1431.

5 Uzasadnienie do rządowego projektu ustawy o zmianie ustawy — Kodeks karny wykonawczy oraz niektórych innych ustaw z dnia 9 marca 2011 r., druk nr 3961.

6 A. Ornowska, Zmiany prawa karnego wykonawczego wprowadzone $w$ latach 2009-2014 odnoszace się do kary ograniczenia wolności, [w:] Zmiany w prawie karnym wykonawczym w latach 2009-2014, red. A. Kwieciński, Warszawa 2014, s. 173.

Nowa Kodyfikacja Prawa Karnego 46, 2017

(C) for this edition by CNS 
Uchylanie się przez skazanego od odbywania orzeczonej kary ograniczenia wolności obligowało zatem sąd do zarządzenia wykonania zastępczej kary pozbawienia wolności. Ustawodawca nie przywidywał przy tym żadnej możliwości zwolnienia się z obowiązku odbywania kary zastępczej. Zaproponowana przez ustawodawcę zmiana, obowiązująca od dnia 1 stycznia 2012 r., charakteryzowała się zatem szczególną surowością. Dopiero w roku 2015, na skutek uchwalenia ustawy z dnia 20 lutego 2015 r. o zmianie ustawy — Kodeks karny oraz niektórych innych ustaw, dodano art. 65a k.k.w., będący odpowiedzią na zgłaszane postulaty w obrębie złagodzenia rygorów wynikających z zarządzenia kary zastępczej ${ }^{7}$. Ustawodawca przywrócił zatem możliwość wstrzymania wykonania zastępczej kary pozbawienia wolności, gdy skazany złoży pisemne oświadczenie, że podejmie się odbywania kary ograniczenia wolności i podda się rygorom z nią związanym.

Wprowadzone do ustawy rozwiązanie ma istotne znaczenie również z uwagi na wykluczenie przez ustawodawcę możliwości opcjonalnej zamiany kary ograniczenia wolności na zastępczą karę grzywny, wobec dostrzeżenia ułomności obowiązującej do 2012 r. regulacji oraz stosunkowo niewielkiej liczby skazanych na zastępczą karę pozbawienia wolności $\mathrm{w}$ całej populacji więziennej ${ }^{8}$.

Ratio legis tej konstrukcji prawnej (art. 65a k.k.w.) sprowadza się do istotnego ograniczenia wykonywania kar zastępczych. Zasadą powinno być wykonanie kary ograniczenia wolności przede wszystkim w postaci zasadniczej i zgodnie z zasadą traktowania izolacyjnej kary zastępczej jako ultima ratio. Założenie to wpisuje się w ideę reformy prawa karnego, wprowadzonej ustawą z dnia 20 lutego 2015 r. o zmianie ustawy

7 Ustawa z dnia 20 lutego 2015 r. o zmianie ustawy — Kodeks karny oraz niektórych innych ustaw, Dz.U. 2015, poz. 396.

8 Z danych Ministerstwa Sprawiedliwości wynika, że skutki orzekania i wykonywania kary ograniczenia wolności w ostatnim dziesięcioleciu nie miały istotnego negatywnego wpływu na populację więzienną. W ostatnich latach w liczbie 80-90 tys. osadzonych jedynie 2-4 tys. skazanych odbywało karę zastępczą pozbawienia wolności z powodu uchylania się od uiszczenia grzywny lub niewykonywania kary ograniczenia wolności - Uzasadnienie do rządowego projektu ustawy o zmianie ustawy - Kodeks karny wykonawczy oraz niektórych innych ustaw z dnia 20 lutego 2015 r., druk nr 2393.

Nowa Kodyfikacja Prawa Karnego 46, 2017

(C) for this edition by CNS 
— Kodeks karny oraz niektórych innych ustaw ${ }^{9}$. Zasadniczym bowiem jej celem była zmiana dotychczasowej polityki karania w kierunku wprowadzenia priorytetu kar wolnościowych, a w konsekwencji ograniczenie stosowania kosztownej i jednocześnie nieskutecznej kary pozbawienia wolności ${ }^{10}$.

Instytucja przewidziana w treści art. 65a k.k.w. pozwala na wstrzymanie wykonania zastępczej kary pozbawienia wolności w wypadku, gdy skazany oświadczy na piśmie, że podejmie odbywanie kary ograniczenia wolności i podda się rygorom z nią związanym. Wprowadzone do ustawy rozwiązanie prezentuje wysoki walor wychowawczy, a także ogranicza populację penitencjarną oraz wydatki budżetowe w tym zakresie. Jest ono zatem alternatywą dla zastępczej kary pozbawienia wolności. W piśmiennictwie ta forma wykonania kary ograniczenia wolności poddawana jest idącej krytyce. Przede wszystkim wskazuje się na brak możliwości osiągnięcia celów kary, o których mowa w art. 67 k.k.w., z uwagi na stosunkowo krótki czas trwania zastępczej kary pozbawienia wolności ${ }^{11}$.

Można więc uznać, że wprowadzone zmiany w wykonywaniu kary ograniczenia wolności będą sprzyjać nie tylko uelastycznieniu, ale również rozszerzeniu stosowania tej kary i zwiększeniu jej efektywności ${ }^{12}$.

${ }^{9}$ Ustawa z dnia 20 lutego 2015 r. o zmianie ustawy - Kodeks karny oraz niektórych innych ustaw, Dz.U. 2015, poz. 396.

10 W opinii Rady Legislacyjnej o projekcie ustawy o zmianie ustawy — Kodeks karny oraz niektórych innych ustaw z dnia 1 lutego 2014 r. wskazano, „że na etapie postępowania wykonawczego należy kłaść nacisk na realizację prawomocnie orzeczonej kary w ramach różnych opcji i konfiguracji prawnych, przewidując większą elastyczność postępowania i zwiększoną dyspozycyjność organów penitencjarnych w realizacji orzeczonych kar i innych środków podlegających wykonaniu. Temu celowi mają służyć nowe możliwości decyzyjne, zmierzające do poprawienia skuteczności ściągania grzywien i należności sądowych oraz, ukierunkowane na analogiczny efekt, nowe rozwiązania w zakresie wykonywania kar zastępczych. [...] W tych rozwiązaniach chodzi o ograniczenie detencji na rzecz środków wolnościowych i nacisk na realizację pracy społecznej. Z tą myślą w prowadza się też nowy środek w postaci wstrzymania wykonania zastępczej kary pozbawienia wolności (art. 65a k.k.w.)" — www.radalegislacyjna.gov.pl (dostęp: 3 maja 2017).

${ }^{11}$ K. Postulski, Orzekanie i wykonywanie zastępczej kary pozbawienia wolności (stan prawny, obawy, propozycje), „Probacja” 2013, nr 2, s. 49.

12 T. Szymanowski, Nowelizacja prawa karnego wykonawczego — przeglad ważniejszych zagadnień, „Palestra” 2015, nr 7-8, s. 188.

Nowa Kodyfikacja Prawa Karnego 46, 2017

(C) for this edition by CNS 
W świetle powyższego rozważenia wymaga charakter instytucji, o której mowa w treści art. 65a k.k.w. Ustawodawca wskazuje bowiem, że po spełnieniu określonych tam przesłanek sąd może w każdym czasie wstrzymać wykonanie zastępczej kary pozbawienia wolności. Zapis ten sygnalizuje fakultatywność orzeczenia w analizowanym zakresie przez użycie zwrotu „może”. Tymczasem szczegółowa analiza powołanego przepisu wzmacnia dość istotnie charakter przedmiotowej instytucji. Ustawodawca bowiem nie określa sytuacji, w których praktyczne jej zastosowanie będzie niedopuszczalne. Nie wprowadza klauzul generalnych czy jakichkolwiek podstaw ocennych, prowadzących do pełnej uznaniowości w analizowanym zakresie. Jedynym kryterium jest złożenie pisemnego oświadczenia o podjęciu odbywania kary ograniczenia wolności i poddaniu się rygorom z nią związanym. Można zatem oczekiwać, iż złożenie przez skazanego stosownego oświadczenia będzie skutkowało wstrzymaniem wykonania zastępczej kary pozbawienia wolności. Na problem ten zwracał już uwagę R. Giętkowski, który wskazywał, iż „decyzja sądu w tym zakresie jest co prawda fakultatywna, ale co do zasady powinna być pozytywna, chyba że prawdopodobieństwo wykonania kary ograniczenia wolności jest nadzwyczaj nikłe"13.

Dodatkowym argumentem potwierdzającym pojawiające się na tym tle wątpliwości jest zapis $\S 6$, z którego wynika, iż niedopuszczalne jest ponowne wstrzymanie wykonania tej samej zastępczej kary pozbawienia wolności na podstawie $\S 1$. Należy zatem przyjąć, że zaproponowane przez ustawodawcę rozwiązanie jest jednorazową szansą na uniknięcie odbywania zastępczej kary pozbawienia wolności, co pozostaje zresztą w zgodzie z ideą analizowanej konstrukcji prawnej. Taki sposób wykładni pozostawałby również $\mathrm{w}$ zgodzie $\mathrm{z}$ ratio legis przedmiotowej instytucji.

Tymczasem stosowanie art. 65a k.k.w. zostało pozostawione ocenie sądu. Rozważenia zatem wymaga, jakie okoliczności będą stanowiły podstawę odmowy skorzystania z przedmiotowej instytucji. Problemem bowiem pozostaje brak bliższego sprecyzowania mierników, na podstawie których sąd ustaliłby powyższe okoliczności ${ }^{14}$. Wydaje się, że ocenie będzie podlegała dotychczasowa postawa skazanego, zwłaszcza w zakresie,

13 R. Giętkowski, op. cit., s. 90.

14 K. Dąbkiewicz, Kodeks karny wykonawczy. Komentarz, Warszawa 2015, s. 321.

Nowa Kodyfikacja Prawa Karnego 46, 2017

(C) for this edition by CNS 
w jakim doszło do zarządzenia wykonania zastępczej kary pozbawienia wolności.

Nie trudno dostrzec, że ocena ta będzie przysparzała wielu trudności. Powodem zarządzenia wykonania zastępczej kary pozbawienia wolności w trybie art. $65 \S 1$ k.k.w. jest uchylanie się od odbywania kary ograniczenia wolności (obligatoryjne zarządzenie), ewentualnie uchylanie się od świadczenia pieniężnego lub obowiązków orzeczonych na podstawie art. $34 \S 3$ k.k. (fakultatywne zarządzenie). W przypadku zatem zarządzenia wykonania zastępczej kary pozbawienia wolności prognoza co do rzeczywistego wykonania kary ograniczenia wolności - w przypadku złożenia przez skazanego stosownego oświadczenia - będzie niepewna, szczególnie w przypadku zarządzenia obligatoryjnego. Pamiętajmy, że wstrzymanie wykonania zastępczej kary pozbawienia wolności ma charakter fakultatywny. W takim razie każdorazowa ocena realności wykonania orzeczonej kary ograniczenia wolności w formie podstawowej pozostawiona będzie dyskrecjonalnej władzy sędziego. Przy rozstrzyganiu w przedmiocie wstrzymania wykonania kary zastępczej decydujące znaczenie będzie miała ocena postawy skazanego, która uznana została za uchylanie się od odbywania kary ograniczenia wolności lub obowiązków orzeczonych na podstawie art. $34 \S 3$ k.k., a także rozmiary i formy tego uchylania się. Nie bez znaczenia powinna być też ocena właściwości i warunków osobistych skazanego, która może mieć wpływ na prognozowanie, na ile realne jest podjęcie przez skazanego wykonania pracy społecznie użytecznej ${ }^{15}$.

Istotne znaczenie pod kątem zastosowania przedmiotowej instytucji będzie miało jednak zachowanie skazanego po zarządzeniu wykonania kary zastępczej (zapłata świadczenia pieniężnego, wykonanie obowiązku probacyjnego).

Mając powyższe okoliczności na uwadze, sąd może zatem uznać, że mimo złożenia przez skazanego stosownego oświadczenia wykonanie kary ograniczenia wolności w formie pierwotnej będzie - z uwagi na postawę skazanego — niemożliwe lub niecelowe.

Przeciwko ,warunkowemu” wstrzymaniu wykonania kary może przemawiać przede wszystkim składanie wielu oświadczeń i obietnic w trak-

15 J. Lachowski, Kodeks karny wykonawczy. Komentarz, Warszawa 2016, s. 352.

Nowa Kodyfikacja Prawa Karnego 46, 2017

(C) for this edition by CNS 
cie postępowania wykonawczego co do chęci odbywania kary ograniczenia wolności, z których to zobowiązań skazany się nie wywiązał, a także okres, jaki upłynął od dnia, kiedy skazany miał rozpocząć odbywanie kary ograniczenia wolności.

Wszczęcie postępowania w przedmiocie wstrzymania wykonania zastępczej kary pozbawienia wolności możliwe jest tylko po uprzednim złożeniu pisemnego oświadczenia o podjęciu odbywania kary ograniczenia wolności i poddaniu się rygorom z nią związanym. W piśmiennictwie wskazuje się, że oświadczenie to nie jest wnioskiem skazanego w rozumieniu art. 6 i 19 k.k.w. ${ }^{16}$ Konsekwencją powyższego jest brak konieczności jego uzasadniania. Niemniej, w interesie skazanego leży zwrócenie uwagi sądu na okoliczności usprawiedliwiające jego uprzednie zachowanie, które doprowadziło do zarządzenia kary zastępczej. Ustawodawca nie precyzuje nadto wymogów, jakie spełniać powinno przedmiotowe oświadczenie. Z literalnego brzmienia treści art. 65a $\S 1$ k.k.w. wynika, iż nadawcą oświadczenia może być wyłącznie skazany. Oznacza to, że takiego uprawnienia nie będzie miał obrońca skazanego ustanowiony lub wyznaczony w postępowaniu wykonawczym. Obrońca może w imieniu skazanego sporządzić wniosek o wstrzymanie wykonania zastępczej kary pozbawienia wolności w trybie art. 65a k.k.w., którego nieodzownym elementem będzie oświadczenie sporządzone i podpisane przez skazanego. Warto podkreślić, iż złożenie samodzielnego oświadczenia o podjęciu odbywania kary ograniczenia wolności — bez konieczności formułowania dodatkowego wniosku - będzie stanowiło samodzielną podstawę wszczęcia z urzędu postępowania i wydania stosownego postanowienia. Oświadczenie to skazany może złożyć bezpośrednio do sądu, który wydał orzeczenie w pierwszej instancji (art. 3 § 1 k.k.w.), a także przekazać je kuratorowi, który dostarczy je następnie do sądu ${ }^{17}$.

Postępowanie to zostaje zatem wszczęte wyłącznie z inicjatywy samego skazanego. Sąd bezzwłocznie wyznacza posiedzenie w celu rozpoznania przedmiotowego oświadczenia i wydaje stosowne postanowienie, uwzględniając bądź nie uwzględniając wniosku skazanego o wstrzymanie

16 S. Lelental, Kodeks karny wykonawczy. Komentarz, Warszawa 2017, s. 321; K. Postulski, Kodeks karny wykonawczy. Komentarz, Warszawa 2016, s. 565.

17 Por. G. Piekut, Konsekwencje uchylania się od odbywania kary ograniczenia wolności, „Nowa Kodyfikacja Prawa Karnego” XXXIX, 2016, s. 148.

Nowa Kodyfikacja Prawa Karnego 46, 2017

(C) for this edition by CNS 
wykonania zastępczej kary pozbawienia wolności orzeczonej w miejsce niewykonanej kary ograniczenia wolności. Posiedzenie to odbywa się bez udziału stron. Rozstrzygnięcie w tym zakresie - zarówno pozytywne, jak i negatywne - podlega zaskarżeniu, co wynika wprost z treści art. 65a $§ 3$ k.k.w. W przypadku uwzględnienia wniosku skazanego postanowienie — zgodnie z regułą z art. 9 § 3 k.k.w. — wykonalne jest z chwilą wydania, co oznacza obowiązek natychmiastowego zwolnienia skazanego z zakładu karnego.

Wskazać nadto należy, że ,warunkowe” wstrzymanie wykonania zastępczej kary pozbawienia wolności może nastąpić w każdym czasie. Oznacza to możliwość procedowania w analizowanym zakresie od chwili wydania nieprawomocnego postanowienia o zarządzeniu wykonania kary zastępczej do chwili jej wykonania w całości. Wobec tego nie można wykluczyć sytuacji, kiedy oświadczenie to zostanie złożone w toku posiedzenia, o którym mowa w art. $65 \S 3$ k.k.w. Takie rozwiązanie pozwoli skazanemu na osobisty udział w posiedzeniu, a zatem zagwarantuje pełną realizację prawa do obrony materialnej. Wówczas, uwzględniając wniosek skazanego, sąd w jednym postanowieniu zarządzi wykonanie zastępczej kary pozbawienia wolności, wstrzymując jednocześnie jej wykonanie ${ }^{18}$.

Zauważyć należy, iż w przypadku nieuwzględnienia wniosku skazanego o wstrzymanie wykonania zastępczej kary pozbawienia wolności przepis art. 43lb k.k.w. pozwala na odbycie kary zastępczej poza zakładem karnym w systemie dozoru elektronicznego. Co istotne, zaproponowane rozwiązanie ma zastosowanie również wobec kary pozbawienia wolności orzeczonej w warunkach, o których mowa w art. $37 \mathrm{~b}$ k.k. lub w art. 87 $\S 2$ k.k.

Reasumując, stwierdzić należy, iż ustawodawca przez dodanie do ustawy art. 65a k.k.w. wprowadził dodatkowy mechanizm zapobiegający orzekaniu zastępczych kar pozbawienia wolności. Nie jest to jednak zmiana rewolucyjna. Po pierwsze, ustawa przewidywała już podobne rozwiązanie (art. $65 \S 5$ k.k.w.), po drugie zaś każde orzeczenie wydane w postępowaniu wykonawczym mogło być reformowane w ramach rozwiązania przyjętego w art. $24 \S 1$ k.k.w. Jak słusznie jednak zauważono, sądy bardzo rzadko korzystały z tej możliwości, co przesądza o słuszności

18 K. Dąbkiewicz, op. cit., s. 320.

Nowa Kodyfikacja Prawa Karnego 46, 2017

(C) for this edition by CNS 
wprowadzenia wyraźnej podstawy prawnej, pozwalającej na wstrzymanie wykonania zastępczej kary pozbawienia wolności ${ }^{19}$.

Jak wskazano na wstępie niniejszych rozważań, zasadniczym, aczkolwiek nie jedynym, celem wprowadzenia do ustawy przedmiotowej instytucji było ograniczenie orzekania zastępczych kar pozbawienia wolności, także w przypadku zarządzenia wydanego na podstawie art. $46 \S 1$ k.k.w. w zakresie kary grzywny (art. 48a k.k.w.). Wykonanie zastępczej kary pozbawienia wolności powinno następować tylko w sytuacjach wyjątkowych. Tymczasem, jak wynika z Rocznej Informacji Statystycznej Centralnego Zarządu Służby Więziennej, odsetek skazanych odbywających kary zastępcze wzrósł z 2681 (2014 r.) do 3259 (2016 r.). Liczba orzeczeń wykonywanych w roku 2015 to 2702 . Kwartalna Informacja Statystyczna za I kwartał 2017 r. również nie nastraja optymizmem, albowiem liczba ta wzrosła do $3959^{20}$. W pozostałych latach, począwszy od roku 2001, kształtowała się następująco: 2001 - 1444, 2002 - 1418, 2003 - 1693, $2004-2324,2005-3011,2006-3284,2007-2219,2008-3500$, $2009-3302,2010-3542,2011-3432,2012-4037,2013-2377^{21}$. Z powyższego zestawienia jednoznacznie wynika, że tylko w roku 2012 liczba wykonywanych zastępczych kar pozbawienia wolności przekroczyła granicę 4000 skazanych, co pozostaje zresztą w ścisłym związku $\mathrm{z}$ wprowadzoną w dniu 1 stycznia $2012 \mathrm{r}$. nowelizacją zmieniającą zasady wykonywania kary ograniczenia wolności w kierunku zwiększenia efektywności orzekanych kar.

Odnotowany wzrost dziwi tym bardziej, iż w roku 2015 złagodzono rygory związane z zarządzeniem wykonania kary zastępczej, wprowadzając przy karze ograniczenia wolności dwie niezależne formy zarządzenia: obligatoryjną i fakultatywną. Wydaje się zatem, że założenia, które legły u podstaw wprowadzenia w roku 2015 reformy prawa karnego, w analizowanym zakresie nie znajdują pełnego odzwierciedlenia w praktyce.

19 M. Małolepszy, Kilka uwag na temat reformy systemu sankcji, „Prokuratura i Prawo" 2015, nr 11, s. 38.

20 Ministerstwo Sprawiedliwości. Centralny Zarząd Służby Więziennej. Kwartalna Informacja Statystyczna za I kwartał 2017 r., Warszawa 2017, s. 4.

21 Ministerstwo Sprawiedliwości. Centralny Zarząd Służby Więziennej. Roczna Informacja Statystyczna za lata 2001-2016, http:/www.sw.gov.pl/strona/statystyka-roczna (dostęp: 2 grudnia 2017).

Nowa Kodyfikacja Prawa Karnego 46, 2017

(C) for this edition by CNS 


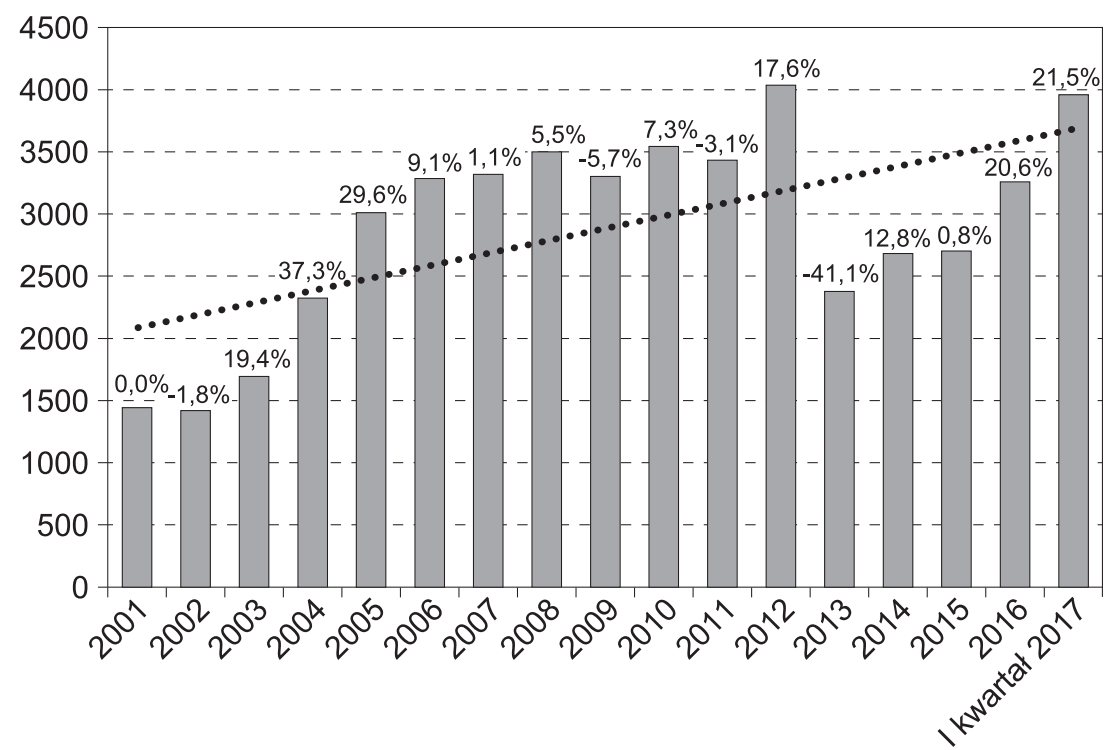

* zastępcza kara pozbawienia wolności za grzywnę orzeczoną samoistnie, zastępcza kara pozbawienia wolności za grzywnę orzeczoną obok kary pozbawienia wolności lub ograniczenia wolności, zastępcza kara pozbawienia wolności za ograniczenie wolności

Wykres 1. Zastępcza kara pozbawienia wolności

Źródło: Roczna Informacja Statystyczna CZSW, http://www.sw.gov.pl (dostęp: 17 czerwca 2017).

Wydaje się, że oparcie na pełnej uznaniowości przedmiotowej instytucji stanowi wyraz pewnej niekonsekwencji ustawodawcy. Być może założenie, które przyświecało wprowadzeniu rozwiązania $\mathrm{z}$ art. $65 \mathrm{a}$ k.k.w., byłoby pełniej realizowane w sytuacji nałożenia na sąd obowiązku jednorazowego wstrzymania wykonania zastępczej kary pozbawienia wolności, po złożeniu przez skazanego pisemnej deklaracji. Prowadziłoby również do usprawnienia pracy sądu, z którego zdjęto by obowiązek ponownej, wnikliwej oceny prognozy kryminologicznej. Jak wynika bowiem z brzmienia art. 65a $§ 2$ k.k.w., jeżeli skazany uchyla się od odbywania kary ograniczenia wolności, sąd zarządza wykonanie zastępczej kary pozbawienia wolności. Nieskorzystanie zatem z jednorazowej szansy na uniknięcie zarządzenia kary izolacyjnej skutkowałoby automatyzmem w zakresie wykonania kary zastępczej, bez konieczności dokonywania szczegółowej analizy zachowania skazanego. Właściwym rozwiązaniem,

Nowa Kodyfikacja Prawa Karnego 46, 2017

(C) for this edition by CNS 
wzmacniającym pozycję zaproponowanej zmiany, byłoby również wprowadzenie dodatkowego mechanizmu dyscyplinującego skazanego, który korzystałby z ,automatycznego” wstrzymania wykonania zastępczej kary pozbawienia wolności w trybie art. 65a k.k.w. Przepis art. $61 \S 1$ k.k.w. pozwala bowiem na ustanawianie, rozszerzanie lub zmianę obowiązków, o których mowa w treści art. 34 § k.k. Obligatoryjne nałożenie na skazanego jednego lub kilku obowiązków z art. $72 \S 1$ pkt 2-7a k.k. w połączeniu z dozorem kuratora sądowego pozwoliłoby na większą kontrolę ze strony organów postępowania wykonawczego oraz stanowiłoby dodatkową dolegliwość dla skazanego korzystającego z rozwiązania przewidzianego w treści art. 65a k.k.w.

\section{Suspension of the execution of the alternative custodial sanction pursuant to Art. 65a of the Executive Penal Code}

Summary

The suspension of the execution of the custodial sanction under alternative sanction presents a high educational value as well as it reduces the incarcerated population and budgetary expenditures in this regard. It is therefore a perfect alternative to the alternative custodial sanction. An essential precondition for the commencement of proceedings for suspension of the execution of the alternative sentencing is a written declaration by the offender about his subjection to the execution of the community sentence and to rigours related to it. Considerations undertaken are based on the solution provided for in Art. 65a of the Executive Penal Code, besides include a dogmatic analysis, focused on the assessment of the character of the institution which is subject of this article. The author notes the absence of legislative consistency - in the context of the ratio legis of the analysed solution - considering the fact, that the title construction is based exclusively on the Court's discretion.

Keywords: written declaration of the offender, alternative custodial sanction, offender's attitude, criminological forecast, community sentence. 